\title{
Chemical composition, in-vitro antibacterial and antioxidant activities of Syzygium aromaticum essential oil
}

\author{
Sidi Mohammed Ammar Selles ${ }^{1,2}\left[\right.$ Mokhtaria Kouidri $^{2} \cdot$ Belkacem Tahar Belhamiti $^{1,2} \cdot$ Amar Ait Amrane $^{1,2}$
}

Received: 28 February 2020 / Accepted: 1 May 2020 / Published online: 13 May 2020

(c) Springer Science+Business Media, LLC, part of Springer Nature 2020

\begin{abstract}
The aims of this study were to investigate the chemical composition, in-vitro antioxidant and antibacterial activities of Syzygium aromaticum essential oil. The essential oil was obtained by hydrodistillation. The GC-MS/GC-FID was used for determination of essential oil composition. The antioxidant activity was determined by DPPH radical scavenging assay and reducing power. The antimicrobial activity was evaluated by the broth microdilution method against six enteropathogens bacteria isolated from diarrhea of young calves. The results of the study revealed an average yield of the essential oil of $11.6 \% \pm 0.97(\mathrm{w} / \mathrm{w})$. About 65 components were identified and quantified. Eugenol was the major compound of the studied essential oil (78.72\%) followed by $\beta$-caryophyllene (8.82\%) and eugenyl acetate (8.74\%). The antioxidant activity by DPPH assay showed IC50 value of $4.82 \pm 0.06 \times 10^{-2} \mu \mathrm{g} / \mathrm{mL}$, while the reducing power assay have resulted an EC50 value of 3.47 $\pm 0.2 \times 10^{-2} \mu \mathrm{g} / \mathrm{mL}$. The results showed that the essential oil exhibited an MIC at $1.36 \mathrm{mg} / \mathrm{mL}$ to $2.72 \mathrm{mg} / \mathrm{ml}$ and $\mathrm{MBC}$ at $5.45 \mathrm{mg} / \mathrm{mL}$ to $10.9 \mathrm{mg} / \mathrm{mL}$ against all tested bacteria. The present investigation revealed that Syzygium aromaticum essential oil exhibited a good in-vitro antioxidant and moderate in-vitro antibacterial activities.
\end{abstract}

Keywords Syzygium aromaticum $\cdot$ Essential oil $\cdot$ Antimicrobial activity $\cdot$ Antioxidant activity $\cdot$ Enteropathogens bacteria

\section{Introduction}

Since last decades, natural products and their compounds have been the most productive source for new drug development [1]. Cloves (Syzygium aromaticum, syn. Eugenia aromaticum or Eugenia caryophyllata) are the aromatic dried flower buds [2]. It belongs to the genus Eugenia (family Myrtaceae). Commonly known as clove. It is broadly used in cooking, pharmacy, perfumery and cosmetics [3].

Syzygium aromaticum is commenly used in food preparation, as an anti-cancer agent and as a traditional remedy for asthma, digestive system disorder, dental disorders, respiratory disorders, headaches and sore throats in Asian countries [4]. Additionally, in traditional medicine, clove is widely used for treatment of dyspepsia, gastritis and

Sidi Mohammed Ammar Selles

nuider10@yahoo.fr;

sidimohammedammar.selles@univ-tiaret.dz

1 Laboratory of Research on Local Animal Products, University of Tiaret, 14000 Tiaret, Algeria

2 Institute of Veterinary Sciences, University of Tiaret, 14000 Tiaret, Algeria diarrhea. Furthermore as antipyretic, aphrodisiac, appetizer, expectorant, antiemetic, anxiolytic, myorelaxant, analgesic, decongestant, anti-inflammatory and hypnotic [3]. Besides the reported antimicrobial, antifungal, antiviral, antioxidant and insecticidal properties, the essential oil of Syzygium aromaticum shows anti-inflammatory, cytotoxic and anesthetic activities [5].

Neonatal calf diarrhea (NCD) is an important cause of severe economic losses in newborn calves worldwide in the livestock industry. These serious economic losses resulting from morbidity, poor growth rates, treatment costs, and mortality among affected young calves [6-8]. Enterotoxic Escherichia coli, Rotavirus, Coronavirus and Cryptosporidium parvum are the four most important enteropathogens causing NCD worldwide [6, 7].

Bacterial antimicrobial resistance is an emerging and serious public health concern especially in veterinary medicine, due to the possible transfer of resistance genes between animal and human strains [9]. This is the consequence of the use of antimicrobials in animals [10]. Pereira et al. [11] reported that a common practice in many dairies is to use sub-therapeutic levels of antimicrobials, such as tetracycline and neomycin, added to milk or milk replacers for disease 
prophylaxis and growth promotion, and to improve feed efficiency. Multidrug-resistant (MDR) Enterobacteriaceae are becoming a major worldwide concern in veterinary medicine $[12,13]$. A high rate $(68.75 \%)$ of MDR of E. coli isolated from neonatal diarrhea in calves less than 30 days old has been reported by [14].

The aims of the present study were to assess the chemical composition, antioxidant and the antibacterial activities of Syzygium aromaticum essential oil against several enteropathogens bacteria isolated from diarrhea of young calves.

\section{Materials and methods}

\section{Extraction of essential oil}

Clove flower buds (S. aromaticum) were purchased from local market in Tiaret (Algeria). Clove flower buds was crushed using mortar and pestle. The crushed clove bud was stored in dark container for future use. The essential oil of clove flower buds was extracted by hydro-distillation for $1 \mathrm{H} 30^{\prime}$ by mixing $20 \mathrm{~g}$ of crushed clove bud in $500 \mathrm{ml}$ of distilled water. The obtained oil was collected and dried over anhydrous sodium sulfate and stored in amber vials with screw cap in a refrigerator at $4{ }^{\circ} \mathrm{C}$ prior to analysis. The percentage yield of Syzygium aromaticum essential oil was calculated using the following formula.

Yield of essentialoil $=\frac{\text { essential oils weight }(\mathrm{g})}{\text { sample weight }(\mathrm{g})} \times 100$

\section{Analysis of essential oil}

The essential oil from flower buds of Syzygium aromaticum was analysed by gas chromatography (GC-FID) and gas chromatography-mass spectrometry (GC/MS) realized by Pyrenessences Analysis. Briefly, the oil was analyzed using a Hewlett Packard 5973, with HP INNOWAX polar column $(60 \mathrm{~m} \times 0.25 \mathrm{~mm} \times 0.25 \mu \mathrm{m})$. One microliter of essential oil diluted in ethanol (10\%) was injected and analysed. Helium was the carrier gas with a flow rate of $30 \mathrm{psi} / \mathrm{FID}, 23 \mathrm{psi} /$ MS. Column temperature was initially kept at $60^{\circ} \mathrm{C}$ for 6 min and then gradually increased to $250{ }^{\circ} \mathrm{C}$ at $2{ }^{\circ} \mathrm{C} / \mathrm{min}$ rate and finally held for $10 \mathrm{~min}$ at $250{ }^{\circ} \mathrm{C}$. The temperature of the injector was fixed to $250{ }^{\circ} \mathrm{C}$ and the one of the detectors (FID) to $270{ }^{\circ} \mathrm{C}$. The compounds were identified by a combined search of retention time and mass spectra (NKS library, 75.000 spectra). The percentages are calculated from the peak areas given by the GC/ FID, without the use of correction factor.

\section{Antimicrobial study}

\section{Microorganisms}

The antimicrobial activity of $S$. aromaticum essential oil was evaluated against seven strains of Gram-negative bacteria (Escherichia coli F5, Escherichia coli CS31A, Kluyvera sp., Klebsiella sp., Salmonella sp. and Serratia sp.) isolated from neonatal calves diarrhea.

\section{Preparation of inoculum}

Prior to the experiment, the strains were inoculated onto the surface of Mac Conkey agar media, the inoculum suspensions were obtained by taking five colonies from $24 \mathrm{~h}$ cultures. The colonies were suspended in $5 \mathrm{~mL}$ of sterile saline $(0.85 \% \mathrm{NaCl})$ and shaken for $15 \mathrm{~s}$. The density was adjusted to the turbidity of a $0.5 \mathrm{McF}$ arland Standard (equivalent to $\left.1-5 \times 10^{8} \mathrm{cfu} / \mathrm{mL}\right)$.

\section{MIC and MBC determination of Syzygium aromaticum essential oil}

The estimation of the minimal inhibitory concentration (MIC) and minimal bactericidal concentration (MBC) were measured by the broth micro-dilution method [15]. The essential oil was dissolved in sterilized physiological saline solution $0.85 \%$ (w/v) supplemented with Tween 20 (Sigma) at final concentration of $10 \%(\mathrm{v} / \mathrm{v})$. Serial doubling dilutions of the oils were prepared in a 96-well microtiter plate ranged from 10.9 to $0.34 \mathrm{mg} / \mathrm{mL}$. The inoculum was added to all wells and the plates were incubated at $37{ }^{\circ} \mathrm{C}$ for $24 \mathrm{~h}$. The bacterial growth was visualized by adding $20 \mu \mathrm{L}$ of $0.5 \%$ 2,3,5-triphenyltetrazolium chloride (TTC) aqueous solution [16]. Minimum inhibitory concentration (MIC) was defined as the lowest concentration of the oils that inhibited visible growth (red-colored pellet at the bottom of the wells after the addition of TTC), while the minimum bactericidal concentration (MBC) was defined as the lowest concentration that killed $99.9 \%$ of bacterial cells. To determine MBC, broth was taken from each well without visible growth and inoculated on Mueller Hinton agar for $24 \mathrm{~h}$ at $37^{\circ} \mathrm{C}$. Each experiment was repeated three times.

\section{Antibiotic susceptibility test}

Antimicrobial susceptibility testing of bacteria was carried out by the disk diffusion method using commercial disks, according to the recommendations of committee on standardization of susceptibility testing in veterinary medicine $[17,18]$. The following antimicrobial agents, loaded on the 
disks, were tested: amoxicillin + clavulanic acid (20/10 $\mu \mathrm{g})$, ampicillin $(10 \mu \mathrm{g})$, gentamicin $(10 \mu \mathrm{g})$, tetracycline $(10 \mu \mathrm{g})$, colistin $(10 \mu \mathrm{g})$, trimethoprime/sulfamethoxazole $(1.25 / 23.75 \mu \mathrm{g})$, ofloxacine $(5 \mu \mathrm{g})$ and cifotaxime $(30 \mu \mathrm{g})$. Susceptibility of strains isolates to commonly used antibiotic agents was measured and interpreted based on the recommendation of committee on standardization of susceptibility testing in veterinary medicine $[17,18]$.

\section{Antioxidant activity}

\section{Reducing power}

The $\mathrm{Fe}^{3+}$ reducing power of Syzygium aromaticum essential oil was determined by the method of Yen and Duh [19] with some modifications. Essential oil was mixed with $2.5 \mathrm{~mL}$ of phosphate buffer $(0.2 \mathrm{M}, \mathrm{pH} 6.6)$ and $2.5 \mathrm{~mL}$ of $1 \%$ potassium ferricyanide. The mixture was incubated for $20 \mathrm{~min}$ at $50{ }^{\circ} \mathrm{C}$. After incubation, $2.5 \mathrm{~mL}$ of trichloroacetic acid $(10 \%)$ was added to the mixture followed by a centrifugation at $3000 \mathrm{rpm}$ for $10 \mathrm{~min}$. The upper layer $(1 \mathrm{~mL})$ was mixed with $1 \mathrm{~mL}$ of distilled water and $0.5 \mathrm{~mL}$ of ferric chloride $(0.1 \%)$. The absorbance of the obtained solution was measured at $700 \mathrm{~nm}$. A higher absorbance indicates a higher reducing power. Reducing power assay of the sample was expressed by EC50 value. The EC50 value was the effective concentration at which the absorbance was 0.5 and was obtained by interpolation from regression analysis. All tests were carried out in triplicate. Quercetin and ascorbic acid were used as positive controls.

\section{DPPH radical-scavenging assay}

The DPPH radical scavenging assay was determined according to the method described previously by Tien et al. [20]. The scavenging rate on DPPH radicals was calculated according to the formula: Scavenging rate $(\%)=100 \times$ $\left(A_{\text {blank }}-A_{\text {sample }}\right) / A_{\text {blank }}$, where $A_{\text {blank }}$ represents the absorbance of the control reaction (containing all reagents except the tested compound), and $\mathrm{A}_{\text {sample }}$ represents the absorbance of the tested compound.

The antiradical activity was expressed as IC50 $(\mu \mathrm{g} / \mathrm{mL})$, which is defined as the extract concentration necessary to scavenge 50\% DPPH free radicals and is obtained by interpolation from regression analysis. The determination was carried out in triplicate, and the results were expressed as mean values \pm standard deviation (SD). Gallic acid, quercetin and ascorbic acid were used as positive controls.

\section{Statistical analysis}

The assays were performed in triplicate and the results were expressed as the mean values with standard deviations (SD). The significant differences were obtained by a one-way analysis of variance (ANOVA) followed by Tukey's honestly significant difference (HSD) post hoc test $(\mathrm{p}<0.05)$. These statistical analyses were calculated using R software (version 3.3.0/ 2016-05-03).

\section{Results and discussion}

\section{Yield and chemical composition}

The Syzygium aromaticum essential oil was extracted with yield of $11.6 \% \pm 0.7$. This result is in agreement with those of Guan et al. [21] and Nana et al. [22] who obtained $11.5 \%$ and $10.54 \%$, respectively. Although, these results are different from those acquired by several study [23-27] with a yield varying from 0.18 to $7.6 \%$.

Yield difference can be influenced by harvest season and geographical origin [22], extraction technique [21]. However, Guen et al. [21] incriminates the particle size of ground cloves on the yield (The extraction yield increases by decreasing the particle size of the comminuted cloves).

Sixty-five signal peaks related to separate components were obtained by gas chromatography (GC-FID) and gas chromatography-mass spectrometry (GC/MS) in S. aromaticum essential oil, where compounds were shown in Table 1. The main constituents were eugenol (78.72\%), $\beta$-caryophyllene (8.82\%) and eugenyl acetate $(8.74 \%)$.

Several studies indicate that eugenol, $\beta$-caryophyllene and eugenyl acetate are the major compounds of the essential oil of $S$. aromaticum with varying percentages [24, 26, 28-35].

Likewise, Barakat [36] reported that major compounds of $S$. aromaticum the essential essential oil were eugenol (80.19\%), eugenyl acetate (7.91\%), caryophyllene (3.79\%), furan, tetrahydro-3-methyl $(2.26 \%)$ and 2-propanone, methylhydrazone (1.54\%).

Nevertheless, other studies have reported a difference in the majority compounds, namely the study of Lee et al. [4] who have shown that eugenol, $\beta$-caryophyllene, 2-propanone, methylhydrazone, cyclopentane, methyl, furan, tetrahydro-3-methyl and $\alpha$-caryphyllene are the major compounds of $S$. aromaticum essentail oil. While, Sokamte et al. [27] reported that eugenol, $\delta$-Cadinene and $\beta$-elemene are the major compounds of this essential oil.

Previous investigations have demonstrated that the chemical composition of $S$. aromaticum essential oil can be influenced by the condition of the environment, the genotype, the geographical origin, the period of harvest, the place of drying, the temperature and the duration of drying and the method of extraction [4, 32, 27]. 
Table 1 Chemical composition of Syzygium aromaticum essential oil

\begin{tabular}{|c|c|c|c|}
\hline Peak & $\mathrm{RT}(\min )$ & Compounds & $\%$ \\
\hline 1 & 7.2 & Ethanol & 0.28 \\
\hline 2 & 10.5 & $\alpha$-Pinene & 0.01 \\
\hline 3 & 14.7 & $\beta$-Pinene & 0.01 \\
\hline 4 & 17.0 & $\Delta 3$-Carene & 0.01 \\
\hline 5 & 18.9 & 2-Heptanone & 0.03 \\
\hline 6 & 20.0 & Limonene & 0.03 \\
\hline 7 & 20.8 & 1.8-Cineole & 0.04 \\
\hline 8 & 22.1 & Cis- $\beta$-ocimene & 0.01 \\
\hline 9 & 23.3 & Trans- $\beta$-ocimene & 0.01 \\
\hline 10 & 24.0 & Acetate de 2-heptyle & 0.04 \\
\hline 11 & 27.0 & 2-Methyl-6-methylene-1.7-octadien-3-one & 0.01 \\
\hline 12 & 29.2 & 6-Methyl-5-hepten-2-one & 0.01 \\
\hline 13 & 32.8 & 2-Nonanone & 0.03 \\
\hline 14 & 37.6 & $\alpha$-Cubebene & 0.01 \\
\hline 15 & 40.1 & $\alpha$-Copaene & 0.01 \\
\hline 16 & 41,9 & $\beta$-bourbonene & 0,02 \\
\hline 17 & 42.9 & Linalol & 0.01 \\
\hline 18 & 45.6 & $\varepsilon$-Cadinene & 0.01 \\
\hline 19 & 46.8 & 2-Undecanone & 0.01 \\
\hline 20 & 47.1 & Terpinene-4-ol & 0.02 \\
\hline 21 & 47.4 & $\beta$-Caryophyllene & 8.82 \\
\hline 22 & 48.4 & Benzoate de methyle & 0.01 \\
\hline 23 & 50.2 & Pulegone & 0.01 \\
\hline 24 & 50.3 & Acetophenone & 0.02 \\
\hline 25 & 51.0 & Zonarene & 0.01 \\
\hline 26 & 51.2 & Benzoate d'ethyle & 0.02 \\
\hline 27 & 51.4 & Acetate de dihydrocarvyle & 0.04 \\
\hline 28 & 51.8 & $\alpha$-Humulene & 0.95 \\
\hline 29 & 52.8 & $\gamma$-Muurolene & 0.01 \\
\hline 30 & 52.9 & $\alpha$-Terpineol & 0.04 \\
\hline 31 & 53.0 & Acetate de terpenyle & 0.02 \\
\hline 32 & 54.2 & Germacrene D & 0.04 \\
\hline 33 & 54,4 & Cubenene isomere & 0,02 \\
\hline 34 & 54.8 & Acetate de benzyle & 0.03 \\
\hline 35 & 54.9 & $\alpha$-Muurolene & 0.03 \\
\hline 36 & 55.2 & $\alpha$-Selinene & 0.02 \\
\hline 37 & 55.7 & Carvone & 0.15 \\
\hline 38 & 55.8 & $\alpha$-Farnesene & 0.12 \\
\hline 39 & 56.8 & $\delta$-Cadinene & 0.11 \\
\hline 40 & 57.2 & $\gamma$-Cadinene & 0.02 \\
\hline 41 & 57.4 & Alcool terpenique & 0.02 \\
\hline 42 & 58.0 & Salicylate de methyle & 0.10 \\
\hline 43 & 58.5 & Cadina-1.4-diene & 0.02 \\
\hline 44 & 59.1 & $\alpha$-Amorphene & 0.01 \\
\hline 45 & 61.4 & Calamenene & 0.02 \\
\hline 46 & 66.5 & Jasmone & 0.03 \\
\hline 47 & 67.8 & Composé aromatique & 0.01 \\
\hline 48 & 69.9 & Oxyde d'isocaryophyllene & 0.02 \\
\hline 49 & 70.4 & Oxyde de caryophyllene & 0.38 \\
\hline 50 & 71.0 & Methyleugenol & 0.01 \\
\hline
\end{tabular}

Table 1 (continued)

\begin{tabular}{llll}
\hline Peak & RT (min) & Compounds & $\%$ \\
\hline 51 & 73.4 & Epoxy-6.7-humulene & 0.05 \\
52 & 73.8 & Caryophyllenol & 0.01 \\
53 & 74.3 & Cubenol & 0.01 \\
54 & 78.2 & Sesquiterpenol & 0.01 \\
55 & 79.1 & Eugenol & $\mathbf{7 8 . 7 2}$ \\
56 & 82.3 & $\alpha$-Cadinol & 0.01 \\
57 & 83.3 & Acetate d'eugenyle & $\mathbf{8 . 7 4}$ \\
58 & 85.0 & Epoxyde sesquiterpenique & 0.02 \\
59 & 85.6 & Caryophylla-3.7-dien-6-ol & 0.09 \\
60 & 86.6 & Chavicol & 0.14 \\
61 & 87,3 & Epoxyde sesquiterpenique & 0,04 \\
62 & 87.5 & Isoeugenol & 0.02 \\
63 & 89.1 & Epoxyde sesquiterpenique & 0.06 \\
64 & 95.8 & 2.3. 4-trimethoxyacetophenone & 0.03 \\
65 & 100.7 & Benzoate de benzyle & 0.03 \\
& & Total & 99.81 \\
\hline
\end{tabular}

Bold values indicate the majority compounds

\section{Antioxidant activity}

In this study, reducing power and DPPH radical scavenging capacity has been used to evaluate antioxidant activity of $S$. aromaticum essential oil. The reducing power was used to investigate antioxidant activity that is based on the capacity of antioxidants to reduce ferric ions $\left(\mathrm{Fe}^{3+}\right)$ to ferrous ions $\left(\mathrm{Fe}^{2+}\right)$. Table 2 show the $\mathrm{EC}_{50}$ value of reducing power of clove essential oil. The samples were evaluated for their radical scavenging capacity using DPPH assay, which is based on the scavenging of the stable DPPH by an antioxidant. Table 2 summarized the $\mathrm{EC}_{50}$ values of DPPH scavenging activity of clove essential oil.

The $\mathrm{EC}_{50}$ value for $S$. aromaticum essential oil was $3.47 \pm$ $0.2 \times 10^{-2} \mu \mathrm{g} / \mathrm{mL}$ in comparison to $21.22 \pm 1.66 \mu \mathrm{g} / \mathrm{mL}$ and $13.98 \pm 1.99 \mu \mathrm{g} / \mathrm{mL}$ for the standard compound quercetin and ascorbic acid, respectively. However, The $\mathrm{IC}_{50}$ value for

Table 2 Antioxidant activity of Syzygium aromaticum essential oil in reducing power and DPPH assays

\begin{tabular}{lll}
\hline & $\begin{array}{l}\text { Reducing power } \\
\left(\mathrm{EC}_{50}\right) \mu \mathrm{g} / \mathrm{mL}\end{array}$ & $\begin{array}{l}\mathrm{DPPH} \\
\left(\mathrm{IC}_{50}\right) \mu \mathrm{g} / \mathrm{mL}\end{array}$ \\
\hline Quercetin & $21.22 \pm 1.66^{\mathrm{c}}$ & $12.02 \pm 1.3^{\mathrm{a}, \mathrm{b}}$ \\
Gallic acid & - & $5.39 \pm 0.41^{\mathrm{b}}$ \\
Ascorbic acid & $13.98 \pm 1.99^{\mathrm{b}}$ & $6.19 \pm 0.97^{\mathrm{b}}$ \\
$\begin{array}{l}\text { Syzygium aromaticum } \\
\text { essential oil }\end{array}$ & $3.47 \pm 0.2 \times 10^{-2 \mathrm{a}}$ & $4.82 \pm 0.06 \times 10^{-2 \mathrm{a}}$ \\
\hline
\end{tabular}

Each value in the table is represented as mean \pm SD $(n=03)$. Means not sharing the same letter are significantly different (LSD) at $p<$ 0.05 probability level in each column 
S. aromaticum essential was $4.82 \pm 0.06 \times 10^{-2} \mu \mathrm{g} / \mathrm{mL}$ in comparison to the standard compound.

The IC50 values higher than those obtained in our study were mentioned by Chaieb et al. [14] $(0.2 \mu \mathrm{g} / \mathrm{mL})$, Saeed and Shahwar [26] (4.5 $\mu \mathrm{g} / \mathrm{mL})$, Sokamte et al. [27] (23.17 $\mu \mathrm{g}$ / $\mathrm{mL})$, Mahboubi and Mahboubi [28] (26 $\mu \mathrm{g} / \mathrm{mL})$, Singh et al. [11] $(80 \mu \mathrm{g} / \mathrm{mL})$, Zhang [37] $(396.3 \mu \mathrm{g} / \mathrm{ml})$ and Viuda-Martos et al. [38] (380 $\mu \mathrm{g} / \mathrm{mL})$. Singh et al. [11], Chaieb et al. [14] and Viuda-Martos et al. [38] showed that the essential oil $\mathrm{IC}_{50}$ was lower than standards used, which is in agreement with our study.

In the present study, the $\mathrm{EC}_{50}$ value for $S$. aromaticum essential oil was higher then that reported by Zhang [37] with an $\mathrm{EC}_{50}$ of $683.4 \mu \mathrm{g} / \mathrm{mL}$. Viuda-Martos et al. [38] and Saeed and Shahwar [26], have shown the highest capacity of clove essential oil, at different concentrations analyzed, to reduce iron.

Kennouche et al. [30] attributes this surprising antioxidant activity to high concentrations of clove oil in eugenol and eugenyl acetate. Additionally, Sokamte et al. [27] explained this high antioxidant activity by the synergistic interactions between eugenol and the other minority components present in this essential oil.

Three main mechanisms of action of eugenol may explain this interesting antiradical effectiveness: donation of hydrogen followed by the delocalization of the group substituted at the para-position; dimerization between two phenoxylated radicals and complexation of $\mathrm{DPPH}^{*}$ with an aryl radical [27].

\section{Antimicrobial activities}

Regarding the antibiotic susceptibility, all tested strains were resistant to ampicillin, amoxicillin + clavulanic acid, tetracycline, trimethoprime/sulfamethoxazole and ofloxacine (Table 3). The antimicrobial activity of $S$. aromaticum essential oil against Gram-negative bacteria associated with

neonatal calves diarrhoea is shown in Table 4. The MIC obtained in this study ranged from 1.36 to $2.72 \mathrm{mg} / \mathrm{mL}$. While the MBCs varied from 5.45 to $10.9 \mathrm{mg} / \mathrm{mL}$.

In our study, the MIC of the essential oils was determined by the broth micro-dilution method. S. aromaticum essential oil exhibited good in vitro antibacterial activity towards the clinical isolates of neonatal calves diarrhea. Ayoola et al. [23] have reported a low MIC $(0.23 \mathrm{mg} / \mathrm{mL})$ has been necessary for stopping the growth of $E$. coli ATCC35218. Likewise, Alitonou et al. [24] showed a lower value of MIC of $S$. aromaticum essential oil against $E$. coli ATCC 25922, with concentration of $0.2 \mathrm{mg} / \mathrm{mL}$. However, Prabuseenivasan et al. [39] reported a higher concentration $(>1.6 \mathrm{mg} / \mathrm{mL})$ for inhibits the growth of E. coli. Nevertheless, Ayoola et al. [23] cited a MIC of $1.6 \mathrm{mg} / \mathrm{mL}$ against an isolate of $E$. coli. On the other hand Naveed et al. [40] mentioned a higher concentration $(5.4 \pm 1.08 \mathrm{mg} / \mathrm{mL})$ against $E$. coli SS1. Previous studies have reported MICs of $0.2 \%(\mathrm{w} / \mathrm{v})$ against $E$. coli, S. enteritidis and S. typhimurium [31].

In the present study the $S$. aromaticum essential oil exhibited a MBC varied from 5.45 to $10.9 \mathrm{mg} / \mathrm{mL}$. A lower MBC was mentioned by Alitonou et al. [24] with $3.12 \mathrm{mg} / \mathrm{mL}$ against E. coli ATCC 25922.

Table 4 Antimicrobial activity of Syzygium aromaticum essential oil
Table 3 Antimicrobial susceptibility of strains

\begin{tabular}{lllllll}
\hline Antibiotic & $\mathrm{A}$ & $\mathrm{B}$ & $\mathrm{C}$ & $\mathrm{D}$ & $\mathrm{E}$ & $\mathrm{F}$ \\
\hline Ampicillin $(10 \mu \mathrm{g})$ & $\mathrm{R}$ & $\mathrm{R}$ & $\mathrm{R}$ & $\mathrm{R}$ & $\mathrm{R}$ & $\mathrm{R}$ \\
Amoxicillin + clavulanic acid & $\mathrm{R}$ & $\mathrm{R}$ & $\mathrm{R}$ & $\mathrm{R}$ & $\mathrm{R}$ & $\mathrm{R}$ \\
$\quad(20 / 10 \mu \mathrm{g})$ & & & & & \\
Gentamicin $(10 \mu \mathrm{g})$ & $\mathrm{S}$ & $\mathrm{R}$ & $\mathrm{R}$ & $\mathrm{R}$ & $\mathrm{R}$ & $\mathrm{S}$ \\
Tetracycline $(10 \mu \mathrm{g})$ & $\mathrm{R}$ & $\mathrm{R}$ & $\mathrm{R}$ & $\mathrm{R}$ & $\mathrm{R}$ & $\mathrm{R}$ \\
Colistin $(10 \mu \mathrm{g})$ & $\mathrm{S}$ & $\mathrm{R}$ & $\mathrm{S}$ & $\mathrm{S}$ & $\mathrm{R}$ & $\mathrm{R}$ \\
Trimethoprime/sulfamethoxa- & $\mathrm{R}$ & $\mathrm{R}$ & $\mathrm{R}$ & $\mathrm{R}$ & $\mathrm{R}$ & $\mathrm{R}$ \\
zole $(1.25 / 23.75 \mu \mathrm{g})$ & & & & & $\mathrm{R}$ \\
Ofloxacine $(5 \mu \mathrm{g})$ & $\mathrm{R}$ & $\mathrm{R}$ & $\mathrm{R}$ & $\mathrm{R}$ & $\mathrm{R}$ & $\mathrm{R}$ \\
Cifotaxime $(30 \mu \mathrm{g})$ & $\mathrm{S}$ & $\mathrm{R}$ & $\mathrm{R}$ & $\mathrm{S}$ & $\mathrm{S}$ & $\mathrm{R}$ \\
\hline
\end{tabular}

A: E. coli F5, B: E. coli CS31A, C: Klebsilla sp., D: Kluyvera sp., E: Salmonella sp., F: Serratia sp. $R$ resistant, $S$ sensible 
Nazzaro et al. [41] reported that "eugenol acts on bacteria by altering the cell membrane, affecting the transport of ions and ATP, and by changing the fatty acid profile of different bacteria". It also acts against various bacterial enzymes, including ATPase, histidine carboxylase. Moreover, eugenol demonstrated the disintegrating capability in the membrane [42]. This alteration results from the denaturation of the proteins by eugenol and the reaction of this compound with the cell membrane phospholipids changing their permeability [21] and the increase of this causes death of the organism [42].

\section{Conclusions}

The results of our study showed that the $S$. aromaticum essential oil is a rich source of eugenol. This essential oil exhibited a good in-vitro antioxidant and moderate in-vitro antibacterial activities and could be an alternative for the treatment of diarrhea in calves caused by the tested strains. These bioactivities are mainly due to the high content of eugenol in this specie. Nevertheless, additional studies will be needed to justify the potential use of this oil as an antibacterial agent against bacteria causing neonatal calves' diarrhea.

Acknowledgements The authors would like to thank Dr. Hamri Mokhtar for his valuable collaboration during this study. The authors are also grateful to Mr. Benaichata Lazrag for the statistical analysis.

\section{Compliance with ethical standards}

Conflict of interest The authors declare that there is no conflict of interest in this study.

\section{References}

1. L.G. Rocha, J.R. Almeida, R.O. Macedo, J.M. Barbosa-Filho, A review of natural products with antileishmanial activity. Phytomedicine 12, 514-535 (2005)

2. R. Singh, R. Lawrence, K. Lawrence, B. Agarwal, R.K. Gupta, S. Dar, Antioxidant and antibacterial activity of Syzigium aromaticum. Chem. Sci. Trans. 4(1), 239-245 (2015)

3. J. Singh, A. Baghotia, S.P. Goel, Eugenia caryophyllata Thunberg (Family Myrtaceae): a review. Int. J. Res. Pharm. Biomed. Sci. 3(4), 1469-1475 (2012)

4. S. Lee, M. Najiah, W. Wendy, M. Nadirah, Chemical composition and antimicrobial activity of the essential oil of Syzygium aromaticum flower bud (Clove) against fish systemic bacteria isolated from aquaculture sites. Front. Agric. China 3(3), 332-336 (2009)

5. K. Chaieb, T. Zmantar, R. Ksouri, H. Hajlaoui, K. Mahdouani, C. Abdelly, A. Bakhrouf, Antioxidant properties of the essential oil of Eugenia caryophyllata and its antifungal activity against a large number of clinical Candida species. Mycoses 50, 403-406 (2007)

6. J. Al Mawly, A. Grinberg, D. Prattley, J. Moffat, J. Marshall, N. French, Risk factors for neonatal calf diarrhoea and enteropathogen shedding in New Zealand dairy farms. Vet. J. 203, 155-160 (2015)

7. V. Meganck, G. Hoflack, S. Piepers, G. Opsomer, Evaluation of a protocol to reduce the incidence of neonatal calf diarrhoea on dairy herds. Prev. Vet. Med. 118(1), 64-70 (2015)

8. Z. Yadegari, G.N. Brujeni, R. Ghorbanpour, F. Moosakhani, S. Lotfollahzadeh, Molecular characterization of enterotoxigenic Escherichia coli isolated from neonatal calves diarrhea. Vet. Res. Forum 10(1), 73-78 (2019)

9. J.L. Martinez, F. Baquero, Interactions among strategies associated with bacterial infection: pathogenicity, epidemicity and antibiotic resistance. Clin. Microbiol. Rev. 15, 647-679 (2002)

10. J.A. Afema, M.A. Davis, W.M. Sischo, Antimicrobial use policy change in pre- weaned dairy calves and its impact on antimicrobial resistance in commensal Escherichia coli: a cross sectional and ecological study. BMC Microbiol. 19, 217 (2019)

11. R.V.V. Pereira, T.M.A. Santos, M.L. Bicalho, L.S. Caixeta, V.S. Machado, R.C. Bicalho, Antimicrobial resistance and prevalence of virulence factor genes in fecal Escherichia coli of Holstein calves fed milk with and without antimicrobials. J. Dairy Sci. 94, 4556-4565 (2011)

12. J.E. Rubin, J.D.D. Pitout, Extended-spectrum $\beta$-lactamase, carbapenemase and AmpC producing Enterobacteriaceae in companion animals. Vet. Microbiol. 170, 10-18 (2014)

13. A. Shnaiderman-Torban, Y. Paitan, H. Arielly, K. Kondratyeva, S. Tirosh-Levy, G. Abells-Sutton, S. Navon-Venezia, A. Steinman, Extended-spectrum $\beta$-lactamase-producing enterobacteriaceae in hospitalized neonatal foals: prevalence, risk factors for shedding and association with infection. Animals 9, 600 (2019)

14. S.M.A. Selles, M. Kouidri, B.T. Belhamiti, A. Amrane, A. Benia, A.R. Hammoudi, S.M. Kaidi, R. Boukraa, Enteropathogens associated with neonatal calves diarrhea in Tiaret area (Western Algeria). Veterinaria 67(2), 97-103 (2018)

15. National Committee for Clinical Laboratory Standards (NCCLS), Performance Standards for Antimicrobial Susceptibility Test, 9th International Supplement. M100-S9, Clinical and Laboratory Standards Institute, Wayne (1999)

16. N. Radulovic, M. Dekic, Z.S. Radic, R. Palic, Chemical composition and antimicrobial activity of the essential oils of Geranium columbinum L. and G. lucidum L. (Geraniaceae). Turk. J. Chem. 35, 499-512 (2011)

17. MoARD, Standardization of antimicrobial susceptibility testing in the veterinary medicine at the national level, according to WHO recommendations. Ministry of Agriculture and Rural Development, Ministry of Health, Population and Hospital Reform (Democratic and Popular Republic of Algeria), p. 83 (2008)

18. MoARD, Standardization of antimicrobial susceptibility testing in the veterinary medicine at the national level, according to WHO recommendations. Ministry of Agriculture and Rural Development, Ministry of Health, Population and Hospital Reform (Democratic and Popular Republic of Algeria), pp. 181-182 (2011)

19. G.C. Yen, P.D. Duh, Antioxidative properties of methanolic extracts from peanut hulls. J. Am. Oil Chem. Soc. 70, 383-386 (1993)

20. Y.Y. Tien, C.C. Ng, C.C. Chang, W.S. Tseng, S. Kotwal, Y.T. Shyu, Studies on the lactic- fermentation of sugar apple (Annona squamosa L.) puree. J. Food. Drug. Anal. 13(4), 377-381 (2005)

21. W. Guan, S. Li, R. Yan, S. Tang, C. Quan, Comparison of essential oils of clove buds extracted with supercritical carbon dioxide and other three traditional extraction methods. Food Chem. 101, 1558-1564 (2007)

22. W.L. Nana, P. Eke, R. Fokom, I. Bakanrga-Via, D. Begoude, T. Tchana, N.S. Tchameni, J. Kuate, C. Menut, F.F. Boyom, Antimicrobial activity of Syzygium aromaticum and Zanthoxylum xanthoxyloides essential oils against Phytophthora megakarya. J. Phytopathol. 163(7-8), 632-641 (2015) 
23. G.A. Ayoola, F.M. Lawore, T. Adelowotan, I.E. Aibinu, E. Adenipekun, H.A.B. Coker, T.O. Odugbemi, Chemical analysis and antimicrobial activity of the essential oil of Syzigium aromaticum (clove). Afr. J. Microbiol. Res. 2, 162-166 (2008)

24. A.G. Alitonou, F.P. Tchobo, F. Avlessi, B. Yehouenou, P. Yedomonhan, A.Y. Koudoro, C. Menut, D.K. Sohounhloue, Chemical and biological investigations of Syzygium aromaticum L. essential oil from Benin. Int. J. Biol. Chem. Sci. 6(3), 13601367 (2012)

25. O. Rodríguez, R. Sánchez, M. Verde, M. Núñez, R. Ríos, A. Chávez, Obtaining the essential oil of Syzygium aromaticum, identification of eugenol and its effect on Streptococcus mutans. J. Oral Res. 3(4), 218-224 (2014)

26. A. Saeed, D. Shahwar, Evaluation of biological activities of the essential oil and major component of Syzygium aromaticum. J. Anim. Plant Sci. 25(4), 1095-1099 (2015)

27. T.A. Sokamte, D.P.M. Jazet, N.L. Tatsadjieu, In vitro\&nbsp;activity of Syzygium aromaticum against food spoilage fungi and its potential use as an antiradical agent. J. Microbiol. Res. 6(1), 1-7 (2016)

28. M. Mahboubi, M. Mahboubi, Chemical composition, antimicrobial and antioxidant activities of Eugenia caryophyllata essential oil. J. Essent. Oil-Bear. Plants 18(4), 967-975 (2015)

29. I. Safrudin, A. Maimulyanti, A.R. Prihadi, Effect of crushing of clove bud (Syzygium aromaticum) and distillation rate on main constituents of the essential oil. Am. J. Essent. Oils Nat. Prod. 2(3), 12-15 (2015)

30. A. Kennouche, F. Benkaci-Ali, G. Scholl, G. Eppe, Chemical composition and antimicrobial activity of the essential oil of Eugenia caryophyllata cloves extracted by conventional and microwave techniques. J. Biol. Active Prod. Nat. 5(1), 1-11 (2015)

31. B. Poaty, J. Lahlah, F. Porqueres, H. Bouafif, Composition, antimicrobial and antioxidant activities of seven essential oils from the North American boreal forest. World J. Microbiol. Biotechnol. 31, 907-919 (2015)

32. R. Gaylor, M. Jahiel, T. Duclos, P. Ramanoelina, F. Fawbush, P. Danthu, Bud, leaf and stem essential oil composition of Syzygium aromaticum from Madagascar, Indonesia and Zanzibar. Int. J. Basic Appl. Sci. 3(3), 224-233 (2014)

33. X.-W. Huang, Y.-C. Feng, Y. Huang, H.-L. Li, Chemical composition, antioxidant and the possible use as skin-care ingredient of clove oil (Syzygium aromaticum (L.) Merr. \& Perry) and citronella oil (Cymbopogon goeringii) from China. J. Essent. Oil Res. 25(4), 315-323 (2013)

34. J.A. Pino, R. Marbot, J. Agüero, V. Fuentes, Essential oil from buds and leaves of clove (Syzygium aromaticum (L.) Merr. et Perry) grown in Cuba. J. Essent. Oil Res. 13(4), 278-279 (2001)

35. A. Dzamic, M. Sokovic, M.R. Ristic, S. Grijic-Jovanovic, J. Vukojevic, P.D. Marin, Chemical composition and antifungal activity of Illicium verum and Eugenia caryophyllata essential oils. Chem. Nat. Compd. 45(2), 259-261 (2009)

36. H. Barakat, Composition, antioxidant, antibacterial activities and mode of action of clove (Syzygium aromaticum L.) buds essential oil. Br. J. Appl. Sci. Technol. 4(13), 1934-1951 (2014)

37. K. Zhang, Chemical composition and antioxidant activities of the essential oil from the clove buds (Syzygium aromaticum) toward various oxidative stresses in vitro. Agric. Food Sci. Res. 2(1), 19-24 (2015)

38. M. Viuda-Martos, Y.R. Navajas, E.S. Zapata, J. Fernández-López, J.A. Pérez-Álvarez, Antioxidant activity of essential oils of five spice plants widely used in a Mediterranean diet. Flavour Fragr. J. 25, 13-19 (2010)

39. S. Prabuseenivasan, M. Jayakumar, S. Ignacimuthu, In vitro antibacterial activity of some plant essential oil. BMC Complement Altern. Med. 6, 10 (2006)

40. R. Naveed, I. Hussain, M.S. Mahmood, M. Akhtar, In vitro and in vivo evaluation of antimicrobial activities of essential oils extracted from some indigenous spices. Pak. Vet. J. 33(4), 413417 (2013)

41. F. Nazzaro, F. Fratianni, L. de Martino, R. Coppola, V. de Feo, Effect of essential oils on pathogenic bacteria. Pharmaceuticals 6, 1451-1474 (2013)

42. K.P. Devi, S.A. Nisha, R. Sakthivel, S.K. Pandian, Eugenol (an essential oil of clove) acts as an antibacterial agent against Salmonella typhi by disrupting the cellular membrane. J. Ethnopharmacol. 130, 107-115 (2010)

Publisher's Note Springer Nature remains neutral with regard to jurisdictional claims in published maps and institutional affiliations. 